Portland State University

PDXScholar

$11-22-2019$

\title{
Erotic Manga, its Artists, and the Pressures of Censorship
}

Dominique Andrée Lief

Portland State University

Follow this and additional works at: https://pdxscholar.library.pdx.edu/honorstheses

Part of the Graphic Design Commons, Illustration Commons, and the Japanese Studies Commons Let us know how access to this document benefits you.

\section{Recommended Citation}

Lief, Dominique Andrée, "Erotic Manga, its Artists, and the Pressures of Censorship" (2019). University Honors Theses. Paper 802.

https://doi.org/10.15760/honors.820

This Thesis is brought to you for free and open access. It has been accepted for inclusion in University Honors Theses by an authorized administrator of PDXScholar. Please contact us if we can make this document more accessible: pdxscholar@pdx.edu. 
Erotic Manga, Its Artists, and the Pressures of Censorship

by

Dominique Lief

An undergraduate honors thesis submitted in partial fulfillment of the requirements for the degree of

Bachelor of Arts

in

University Honors

and

Japanese

and

Graphic Design

Thesis Adviser

Jon Holt, Ph.D.

Portland State University 


\section{Overview}

I can remember embarrassingly well how I first came across ero manga (erotic Japanese comics) at around age ten or eleven. I had just started getting into manga after serendipitously wandering into the Teen's comic section at my public library, and I noticed a thick, red book in the featured section. It was Manga: The Complete Guide by Jason Thompson (2007), with the word "manga" plastered on the front cover. "Well hey, I like manga," my fifth-grader brain thought enthusiastically. I checked it out and upon reading it at home, I noticed there was one especially tantalizing chapter in the contents: "Adult Manga." I flipped to the back of the book, where the author had tried to hide the adult manga away from my prying eyes. Truthfully, it was horribly boring; there were almost no pictures! But there was one manga page that caught my eye, a page from the English localization of Yonekura Kengo's Pink Sniper (2006). The dynamic of the characters' interactions, the aesthetically appealing the art style, Thompson's promise of a four-star manga experience featuring "a

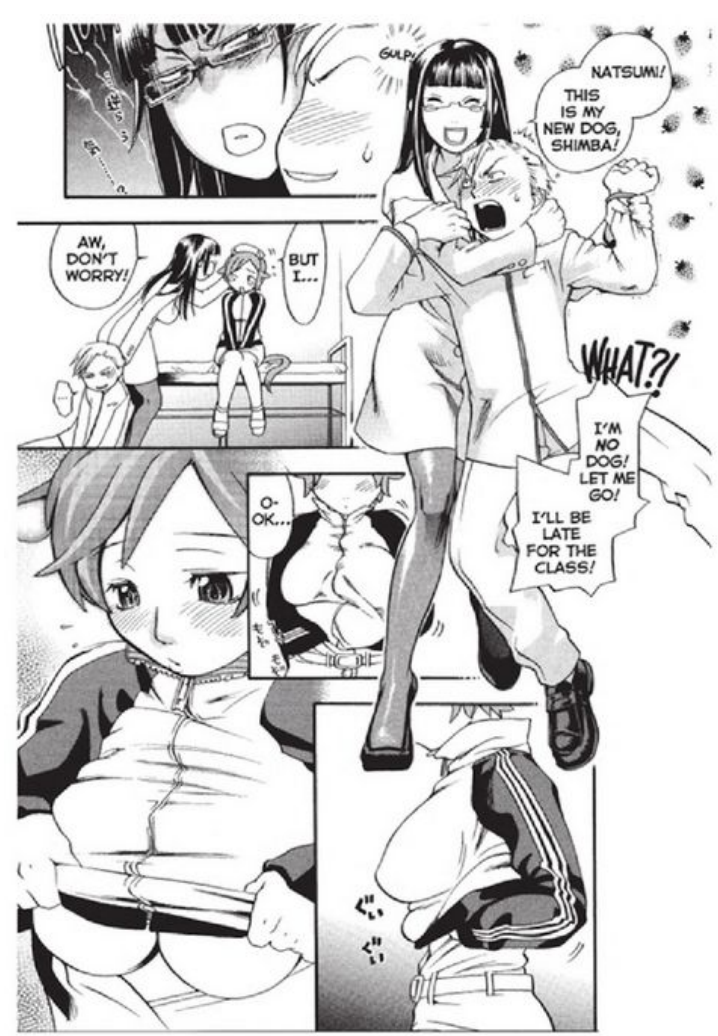

Figure 1. Example page from Pink Sniper from Thompson, Jason: Manga: The Complete Guide, 9 October 2007, p. 464.

high school of humans and anthro-humans...where

unsuspecting students find themselves at the mercy of the wildly sexual school nurse," and my prepubescent brain yelling "She's gonna show her boobies!?!?” implored me to look up Pink Sniper. From that day forward, I was hooked, but only secretly; my mother already feared that I 
was reading "those sicko pervert comics." Little did she know that I would lean more into the genre as my life progressed.

Although hobbies and interests come and go, both pursuing Japanese language study and reading erotic manga never faded from my mind. Fast forward through middle school, where I taught myself both hiragana and katakana scripts, and high school, where I spent my free time browsing the Japanese art site Pixiv and trying to decipher the dialogue of countless graphic boy's love (BL) comics with my kana skills and all twenty of the Japanese words I knew. Near the end of high school and beginning of college, through a series of fortunate events, I worked my way into an internship-turned-job at FAKKU!, the largest English erotic manga publisher currently in the world. As I was becoming aware of the erotic manga industry through my job experience, questions started to well up within me about the regulations in place for erotic two-dimensional content.

Both Pink Sniper and the manga I typeset at work are uncensored. This is because both are published legally in English for audiences outside of Japan, meaning the uncensored files were given for overseas distribution. The average erotic manga consumer is no stranger to the wide spectrum of censorship methods found in Japanese publications, ranging from large white blobs that cover the entire crotch region to skinny black lines that leave almost nothing to the imagination. I was lucky enough to study abroad in Tokyo for a year, and during my summer vacation I drew and made a dojinshi (self-published comic) to experience the process that so many professional erotic manga artists do as a side hobby. When it came time to censor it adequately enough to sell at a comic market, I had no idea how much or even what to censor. There are no definitive guides, and standards vary from books to magazines and events to events. 
I asked two artist friends of mine, who create erotic manga professionally, for assistance, but even they did not have solid answers beyond "I think that's good enough." Even industry professionals could not quite put into words how to censor erotic manga. Having then gone through the process of self-censorship, I later asked one of those friends how they felt about the censorship of their work, to which they responded along the lines of "Well, I feel like it's kind of a waste after drawing it all, but it can't be helped." This leads me to my research question-How do erotic comic artists in Japan perceive the censorship of their works, and, if I may slightly reframe the question, in order to create erotic content, how do they adjust their creative expression to meet or challenge those limitations?

I am sure almost every non-Japanese fan of erotic manga has asked themselves at one point or another "How is erotic manga censored?" or "What kind of content is censored?" and inevitably "Why is erotic manga censored?" However, I will not focus directly on any one of those questions. From a Westerner's perspective, censorship seems to be a foggy expectation that has very real consequences if not adhered to properly. Japanese artists on the other hand, have an innate sense of where the thin boundary between acceptable and unacceptable lies, as difficult to identify as that may be. If one digs enough through English manga studies academia, one can come up with the legislation behind genital obscuration, the movements of mothers and PTAs against erotic manga, and mentions of the effects of erotic manga on society, but little to no mention of it as an art form or any regard towards the artists who create it. This project aims to understand the impact of censorship on erotic manga from the creators' perspectives, a topic and angle that both of which have never been investigated by English-speaking researchers before. 
This research currently does not have an English academic research community to contribute to, as comic studies, especially manga studies, from Western academics are very small, so the academic community for erotic manga is almost non-existent. I hope to make this research act as a bridge between the Japanese and Western manga studies research communities, wherein researchers from Japan can see how international researchers analyze their fields and Western researchers can get a glimpse into Japanese manga studies. I would also like to contribute to the socially-charged conversation regarding so-called "harmful" cartoon pornography that tends to mention hentai (perverted) videos but not include actual Japanese people in the conversation; by recording accounts of conversations with and quotes from creators themselves, I would like to provide a new perspective for other people to consider when discussing two-dimensional erotica.

\section{Methodology}

In this paper, I will be using three types of sources to examine the relationship between erotic manga and its relationship with censorship. The first category is composed of American and British academic book chapters from the 1990s, as those are the most recent publications that could be found regarding erotic manga written in English. The second category is Japanese academic book chapters from the 2010s, most notably from erotic manga and bishōjo (beautiful girl) manga researcher Kimi Rito. This mixture of sources gave me a background in English of how erotic manga and its regulatory laws came to be, and the Japanese sources provided in-depth examples of how that history has played out and shaped the erotic manga industry that exists today. 
In addition to referencing literary sources, I conducted small text-based interviews with erotic manga artists, mostly if not all professionals as opposed to amateurs. I was fortunate enough to develop business relationships, acquaintanceships, and friendships with erotic manga artists during my year-long study abroad, so I have the means to access a population that many other Western researchers may not possess. My interview questions consisted of the following:

- How did you learn to censor manga? Did someone teach you?

- How do you usually prefer to self-censor your work? (Using mosaics, using black bars, censoring words, etc.)

- When drawing erotic manga, do you draw everything, even though it will be censored?

- Do you have any emotional reactions when you have to censor your manga? What kind of emotional reaction?

- What do you think are the pros of censorship?

- What do you think are the cons of censorship?

- If Japan's censorship laws were removed, would your drawing process change? If so, how would it change?

These questions both reference concepts brought forward in Kimi Rito's book The History of Ero-Manga Expression (Eromanga Hyoggen-shi) and draw out insight into how the artists feel the censorship of their works affects the overall quality of the product and the artistic composition. 


\section{Historical Background}

In 1907, Article 175, also known as the Indecency Act, was added to the National Penal Code of Japan and lives in a precarious balance with other pieces of legislature.

This article states:

A person who distributes, sells or displays in public an obscene document, drawing or other objects shall be punished by imprisonment with work for not more than 2 years, a fine of not more than $2,500,000$ yen or a petty fine. The same shall apply to a person who possesses the same for the purpose of sale. (Penal Code)

Article 175 has been in a constant proximity with Clause 21 of Japan's 1946 postwar constitution, which guarantees the right to freedom of speech and publication. The conflict of these two pieces of legislature could be said to come from a desire to be viewed as civilized by Westerners by self-regulating extreme content while also wanting to retain a newly implemented freedom of speech after two centuries of strict government control from the Edo period (1600-1868).

Although the Indecency Act was written in 1907 (Dobbins 2) and implemented in 1964 in relation to manga regulation (Kinsella 140), erotic manga as we know it today began in the early 1970s as a divergent genre branching from gekiga, a genre of dramatic manga aimed at young men that featured realistic drawings and mature themes. After the boom of gekiga in the 1960s, some artists put an erotic spin on the genre, and developed ero gekiga, or erotic gekiga. These gekiga emphasized realism and developed strong readership in the baby boomer generation, who had grown up reading and enjoying children's manga, and they set a robust precedent for erotic manga to grow and prosper. 
Erotic manga continued to develop as a genre, and was heavily influenced by Comic Market, an amateur self-published manga event held twice a year in Tokyo. This influence led to a popularity from about 1980 in young-looking women called bishōjo (beautiful girl) manga and lolicon (Lolita complex) manga. These genres, especially lolicon, could be said to have come into existence because of the Indecency Act. This article had several unstated rules, such as not drawing or showing genitals or even pubic hair. Because the depiction of pubic hair was not allowed, coupled with the public's obsession with cutely drawn characters, the girls in erotic manga began to appear younger and younger often with genatalia that were drawn underdeveloped, and thus rendered with a cartoony look, free of problematic details. Bishōjo and lolicon would continue to be the dominant genres of erotic comics without much backlash until 1989, when Miyazaki Tsutomu was arrested.

In the August of 1989, Miyazaki Tsutomu was found guilty of killing four girls ages four to seven, but also sexually assaulted their corpses, cannibalized parts of their bodies, and wrote letters to the victims' families detailing the murders. The media broke into his room and photographed his immense amount of movies and manga, which included lolicon manga. Not only did the mass media contribute to this subculture witch-hunt, but Miyazaki's defense team “intended to rationalize its client's admitted murders by invoking the media's loaded rhetoric of contemporary public ills, namely the breakdown of social order, the eroticization of children, and the proliferation of of gratuitous images and commodities" (Treat 355). The Japanese public and lawmakers began to assume that media influenced the murders, which led them to examine the manga that their youth were reading. 
The scrutinization of erotic manga began in the early 1990s battles with between pro-regulation and pro-artistic-freedom groups. In terms of pro-regulation, not one group of people was responsible for the push towards erotic manga censorship; it was a wide variety of mother's groups for the protection of children, PTA groups, anti-manga groups, Christian associations, and other groups whose morals aligned and focused on adult manga. On the pro-artistic-expression side, manga artists and their sympathizers were similarly disorganized until The Society to Protect the Freedom of Expression in Manga (Manga Hyōgen wo Jiyū ni Mamoru Kai) was formed in March 1992. The organization was actually formed by Shinoda Hironori, the publisher of an analytic periodical focused on the media and communication industries at the time. The organization recruited over one thousand members two years after its conception. The Society to Protect the Freedom of Expression in Manga was responsible for bringing into public knowledge the degree to which manga was censored; it reduced the number of blacklisted manga overall; and, this group turned the status of "manga artist" into a respectable occupation. Satonaka Machiko, a veteran female artist and member of the society, "suggests that artists should be trusted to censor themselves without the interference of official agencies" (Kinsella 159). In the end, a kind of compromise was reached in which manga artists and their editors and publishers were trusted to self-censor their works.

In terms of censorship, artists usually take it upon themselves to censor their works unless an outside force tells them to edit it further. In the early period of erotic gekiga, genitals just were not drawn to begin with, so there was little to censor. The beginnings of bishōjo manga also did not feature much to censor, as those comics were mostly suggestive with little to no sex scenes. As erotic manga grew in popularity and controversy, climaxing with the Miyazaki case, 
more restrictions on its sales arose, such as adding "adults only" stickers to books and magazines. Even so, these labels provided artists more legroom when it came to depicting pubic hair and genitalia, which was unheard of before the 1990s. Since the 1990s, erotic manga censorship legislation has remained relatively unchanged.

\section{Current Status}

Manga censorship currently hasn't changed significantly since the 1990s, when genitals and pubic hair were allowed to be depicted in more detail, but it has become widely varied and stylistic.

Types of censorship differ based on the context in which the erotic manga is published, such as erotic manga

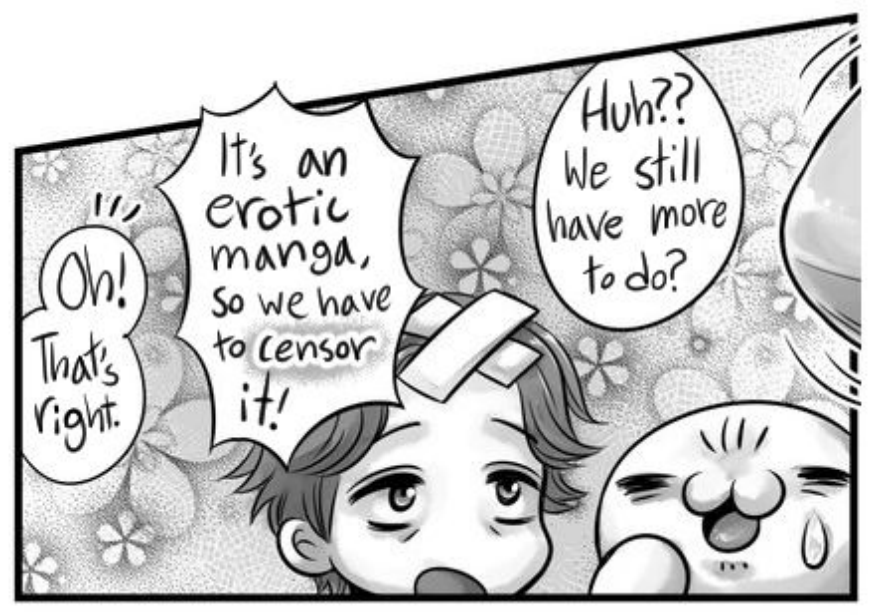

Figure 2. English translated and lettered manga panel from Afostarsan: Masyo no Afostarsan, 30 August 2019. Used and edited with permission from the artist. magazines, books, online distribution, and self-published erotic manga. Some regulations are created by publishers, while others are set in place by self-published comic events. With all of the different contexts that erotic manga can be published and distributed, styles of censorship vary just as much.

In the beginning, when genitals and pubic hair had to be completely nonexistent, erotic manga censorship consisted of completely blotting out crotch areas with large white squares or circles, leaving everything to the imagination. With this level of censorship becoming the norm after the Miyazaki Tsutomu incident, artists started fighting to fill up the empty space by using 
things such as speech bubbles, heart, or star shapes to cover the crotch area. Some artists even used metaphoric objects to stand in for the genitals, such as animals and food.

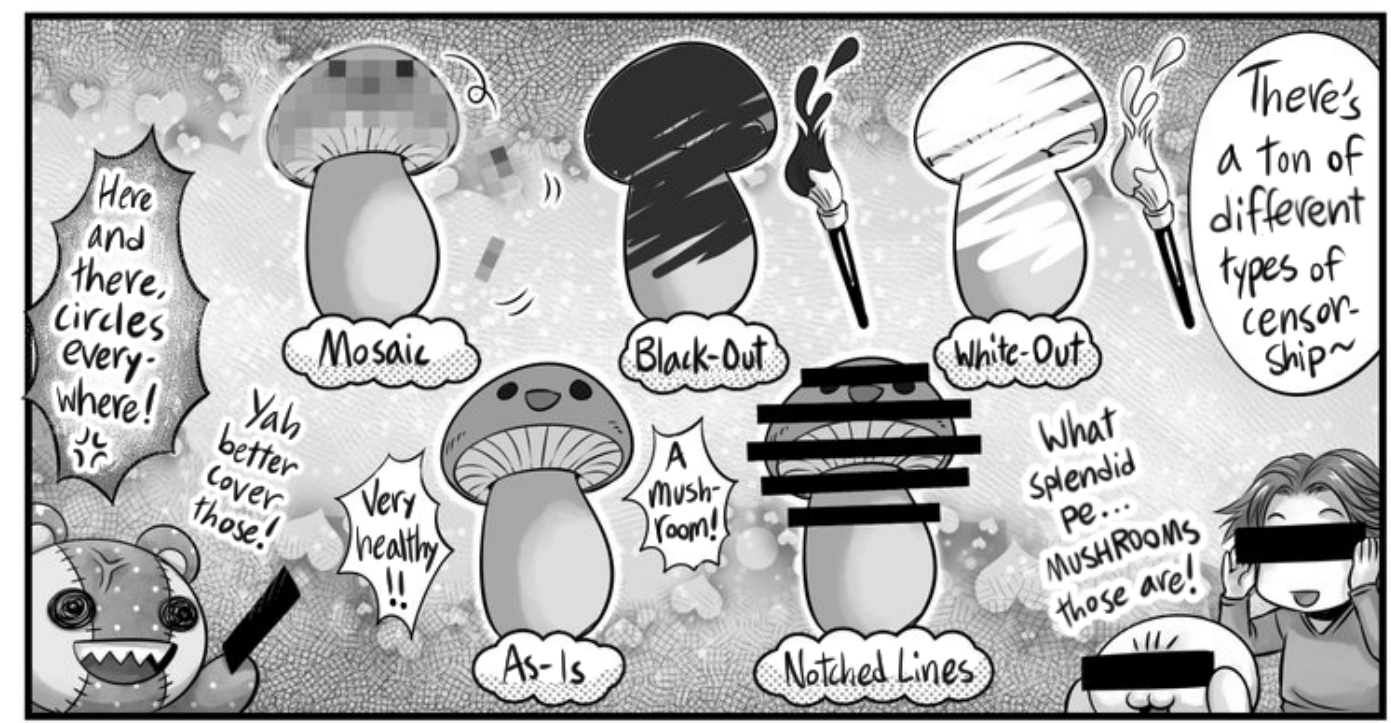

Figure 3. English translated and lettered manga panel from Afostarsan: Masyo no Afostarsan, 30 August 2019. Used and edited with permission from the artist.

After the restrictions were slightly lifted as an effect of the "adults only" stickers, censorship styles became more straightforward and revealing. The most common types of censorship are black and white bars. This can involve either one large bar over the offending area or multiple smaller bars, creating a barcode-like effect. There are also styles that resemble white-out, such as the "lightsaber," which completely whites out the penis and glows a bit beyond the original shape, and a style in which the outlines are left alone but everything else is whited out, making details still seemingly visible. Finally, there is the mosaic, which is most commonly used in erotic manga that are drawn in color, and is used primarily for erotic anime and live action pornography in Japan. 


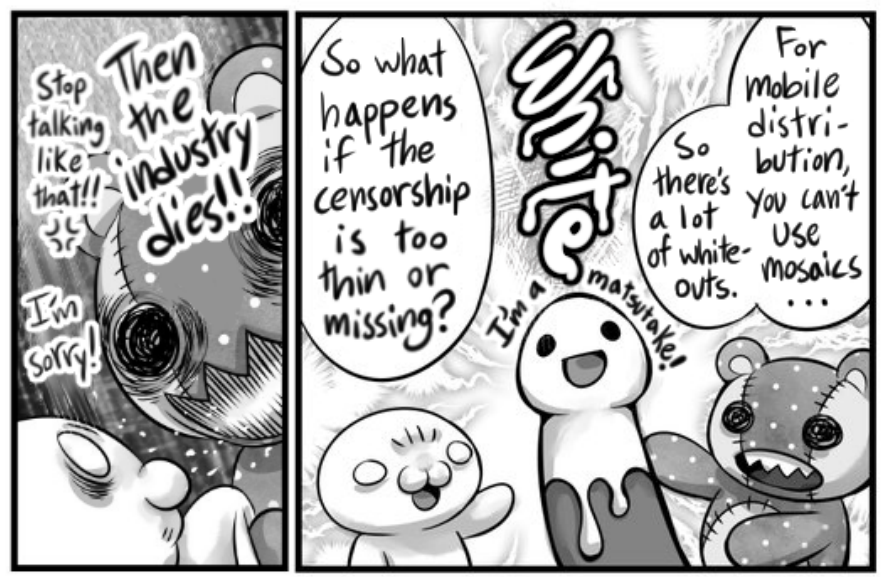

Figure 4. English translated and lettered manga panel from Afostarsan: Masyo no Afostarsan, 30 August 2019. Used and edited with permission from the artist.

Lastly, there are forms of censorship beyond covering genitals that are more content-related. For example, there are many artists who choose to add circles to censor out letters in words relating to genitalia, such as "ma॰ko"; with manko meaning "vagina", the effect would look something like "puosy" in English. There are also broader limitations on content and themes included in erotic manga. For example, some of the highest grossing erotic comic magazines, Kairakuten (lit. a pun on the words “optimism" and "pleasure heaven") and Kairakuten BEAST published by Wanimagazine, are limited to vanilla erotic manga rarely delving into anything that could be considered controversial. Erotic comic artists looking to focus on more niche genres such as schoolgirls, crossdressing boys, fantasy creatures, and eroguro (erotic grotesque) have their own theme-based magazines in which the entire magazine revolves around one genre. These magazines are usually printed less frequently than the top selling, more generic erotic magazines, and they are unlikely to be sold in places like convenience stores or non-adult bookstores. In the past, there were three major things that one could not draw for the covers of erotic manga magazines sold in convenience stores: nipples, 
underwear, and sailor-suit school uniforms. Although sailor suits were not allowed, blazers, another article of clothing commonly associated with school uniforms in Japan, were acceptable (Kimi 307). Another example of the contradiction of content-based censorship is a more recent one, relating to the titles of erotic manga and anime distributed online. Japan is more lax about controversial themes in erotic comics than a majority of the rest of the world, so in order to prevent people outside of Japan stumbling upon this content, the new big three phrases that were not allowed in erotic manga and anime titles are "loli," "rape," and "bestiality." Though this restriction is imposed on titles, the content inside can include any or all of these three themes (Kimi 312).
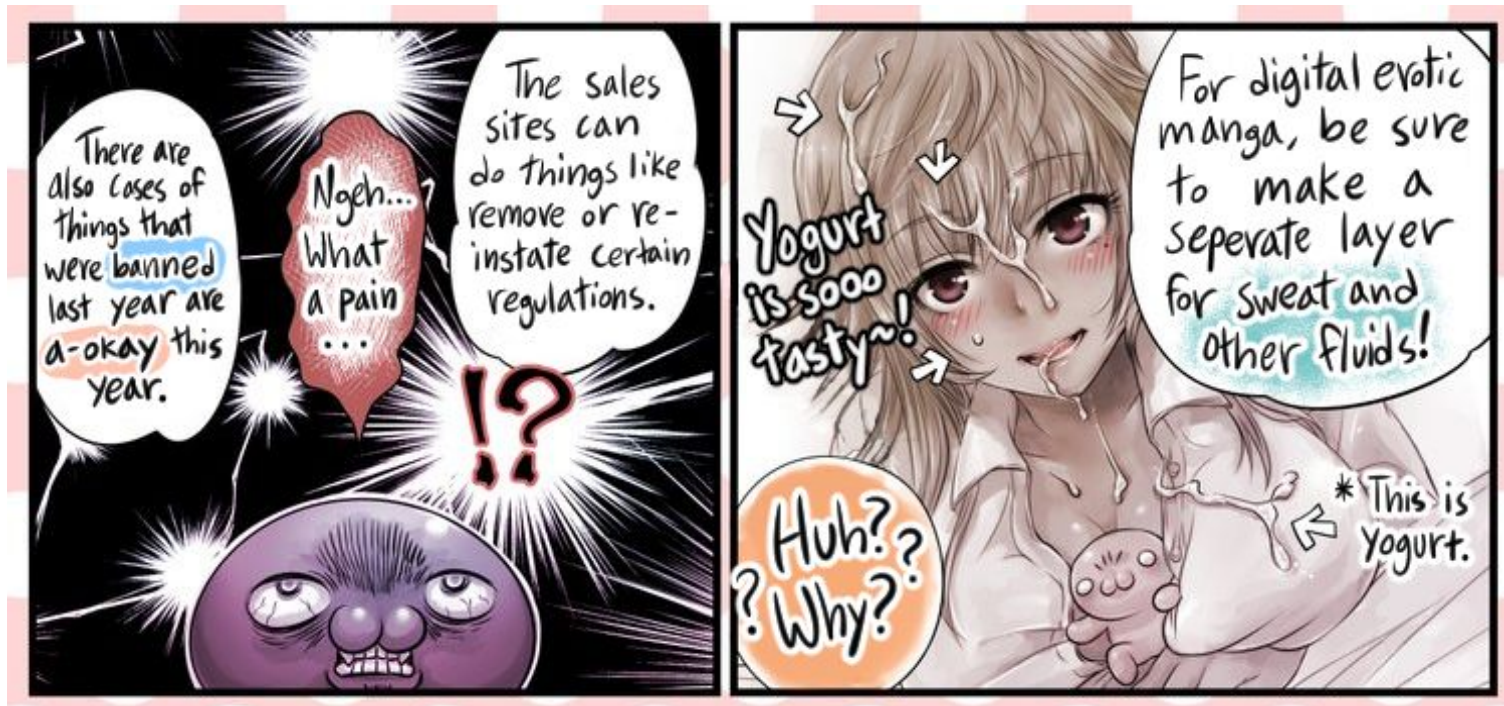

Figure 5. English translated and lettered manga panel from Afostarsan: Masyo no Afostarsan, 30 August 2019. Used and edited with permission from the artist.

Every adult-oriented media company in Japan has to adhere to the Indecency Act, but with the grey definition of "obscene," there are several styles and interpretations of how to censor erotic comics. Although Article 175 states that the most severe punishment facing someone who breaks this law would be "imprisonment with work for not more than 2 years, a 
fine of not more than 2,500,000 yen or a petty fine." So why does the entire industry, including self-publishers, work so hard to stay above this vague piece of legislation with comparatively minor punishments that is rarely enacted? One reason may be a chilling effect caused by the conviction of Suwa Yūji, the erotic manga artist who created the "obscene" manga Honey Room (Misshitsu), and Kishi Monotori, the president of Shōbunkan, the publishing company that released Honey Room. Suwa was fined, and all of his manga were removed from store shelves. Kishi was also fined, arrested for one year, and suspended for three years. In short, this one case provides proof that the Tokyo District Court could and would punish someone for this law, setting all adult-oriented companies into a better-safe-than-sorry mindset. However, if obscenities are such a problem, one would wonder why are they allowed at all. This goes back to Clause 21 of Japan's postwar constitution, which guarantees freedom of expression and speech. These two laws continue to exist and contradict each other, creating a thin line between free expression and obscenity that is still thick enough to censor a penis. As Kimi Rito tweeted on May 6th, 2019:

The only country in the world that censors its erotic manga aimed at adults is Japan. After all, countries that are strict with erotic manga would ban it from being published altogether, and countries that allow adult-oriented manga don't censor it at all. Japan is the only country that believes censoring genitals can alleviate the obscene nature [of erotic manga]! 


\section{Interviews}

Before I present my subject interviews, there are a few things I would like my readers to keep in mind. Firstly, all real names and genders are kept confidential. With five interviewees, complete gender equality was not possible, but I kept balance as possible. Secondly, all interviews were conducted via text through Twitter direct messaging after consent forms were filled out, then translated by the interviewer. Thirdly, all artists interviewed began post-1990s, so their answers only reflect the current climate of erotic manga censorship and not that of the past. Lastly, these are all artists that I have developed positive relationships with, and were not randomly selected from a pool, possibly causing some bias in the responses.

\section{Afostarsan \\ 1. How did you learn to censor manga? Did someone teach you?}

I learned both from books I read and from senior manga artists and editors teaching me.

2. How do you usually prefer to self-censor your work? (Using mosaics, using black bars, censoring words, etc.)

I obscure things with mosaics (モザイク), black bars (黒ベタ), and drawings of cute characters’ faces.

3. When drawing erotic manga, do you draw everything, even though it will be censored?

I usually draw everything out before it's censored. 
4. Do you have any emotional reactions when you have to censor your manga? What kind of emotional reaction?

It makes me very sad (とても悲しくなります). I'll wonder, “Is there even a point to this censorship?"

\section{What do you think are the pros of censorship?}

I think its role is to impose self-restraint (歯止め), to control the reckless “anything goes” (なん でもかんでも OK) mentality.

6. What do you think are the cons of censorship?

I'm afraid of the deterioration where things that don't need to be hidden slowly become things that $d o$ need to be hidden.

7. If Japan's censorship laws were removed, would your drawing process change? If so, how would it change?

I would draw after using my own judgement to decide what should be hidden and what should be revealed. I would decide which parts to restrain myself, not just in censorship but in the content and dialogue as well for the manga as a whole. 


\section{Aoi Miharu}

\section{How did you learn to censor manga? Did someone teach you?}

I don't have any experience in self-publishing manga, so usually at work the publishing company would go ahead and censor my work for me. I've only censored manga myself about twice, and those times the publishing company advised me on how to do it and revised it for me.

2. How do you usually prefer to self-censor your work? (Using mosaics, using black bars, censoring words, etc.)

When I've censored my manga myself, at the instruction of the publishing company, I whited-out (真っ白に塗っていました) the genitals.

\section{When drawing erotic manga, do you draw everything, even though it will be censored?}

Besides occasions when I didn’t have enough time, I draw everything out.

\section{Do you have any emotional reactions when you have to censor your manga? What kind of emotional reaction?}

I don't feel anything particularly noteworthy when I censor my work, but I do think about how nice it would be to display my work without censorship. However, when works without censorship at all start circulating too much, I feel our immoral industry gets damaged not by our lack of morality but from another immorality that gets generated by the need to censor the art.

Excessive censorship doesn't have a very good image. 


\section{What do you think are the pros of censorship?}

Censorship creates a feeling of immorality. I feel that if everything were to be shown out in the open, and staring wide-eyed at everything became normalized, the feelings felt while looking at erotic manga would become similar to the primal urges of some kind of caveman, and it would spoil the sense of eroticism.

If I could, I think it'd be good to leave only one thing uncensored per work.

\section{What do you think are the cons of censorship?}

To both artists and readers, it's too bad that they can't see the expressly beautifully drawn pictures that are censored.

7. If Japan's censorship laws were removed, would your drawing process change? If so, how would it change?

It depends on the work, but if censorship was removed I would maybe draw closeups more clearly. I think the same could be said for [erotic manga] magazines in general.

\section{MEME50}

\section{How did you learn to censor manga? Did someone teach you?}

In terms of self-published works, I would refer to artists that have done it before.

For professional work, the editing department censors it for me. 
2. How do you usually prefer to self-censor your work? (Using mosaics, using black bars, censoring words, etc.)

I use black bars.

3. When drawing erotic manga, do you draw everything, even though it will be censored?

I draw everything, even if it will be censored.

4. Do you have any emotional reactions when you have to censor your manga? What kind of emotional reaction?

In Japan, you can't publish manga if you don't censor the genitals, but I get the feeling that even the magazine publishers want to show the content uncensored.

5. What do you think are the pros of censorship?

The fact that it's done so that minors won't see it?

Even though erotic manga is made specifically for adults.

6. What do you think are the cons of censorship?

The fact that depending on the situation, it can disrupt the production.

7. If Japan's censorship laws were removed, would your drawing process change? If so, how would it change?

I don't think I would change anything. 


\section{Poccora}

1. How did you learn to censor manga? Did someone teach you?

I learned from copying self-published comics that I already owned and from Comic Market's official announcements.

2. How do you usually prefer to self-censor your work? (Using mosaics, using black bars, censoring words, etc.)

Only black bars. It fits well with the distribution platform I use.

3. When drawing erotic manga, do you draw everything, even though it will be censored?

I draw everything out. If you want to know why, it's because the bits that aren't covered by the black bars are still visible.

4. Do you have any emotional reactions when you have to censor your manga? What kind of emotional reaction?

It feels stupid, because neither the artists nor users want it.

5. What do you think are the pros of censorship?

There are none.

6. What do you think are the cons of censorship? 
There are situations where it will make me reluctantly cover parts that I wanted to show. It also adds to the workload.

7. If Japan's censorship laws were removed, would your drawing process change? If so, how would it change?

I don't think I would really change anything, because I don't consider the censorship when I draw.

\section{Yamada Konayuki}

\section{How did you learn to censor manga? Did someone teach you?}

I loved erotic manga from the beginning, so I unconsciously learned to what degree things needed to be censored from the magazines and books that I had bought. Also, I make self-published comics, and whenever the publisher warns me that it isn't censored enough, I update that previous knowledge in my head.

2. How do you usually prefer to self-censor your work? (Using mosaics, using black bars, censoring words, etc.)

For self-published works:

* I use black bars to cover parts of the images.

* I add $\circ$ (circles) to words

For professional works: 
* The editing department censors it according to their standard process

3. When drawing erotic manga, do you draw everything, even though it will be censored?

I still draw parts that will be removed by censorship.

4. Do you have any emotional reactions when you have to censor your manga? What kind of emotional reaction?

It's very unfortunate that the things that I took the trouble to work so hard on drawing aren't able to be seen.

\section{What do you think are the pros of censorship?}

I personally don't understand the necessity of genital censorship, so I can't really think of a pro to it.

\section{What do you think are the cons of censorship?}

From a manga artist's perspective, I think having parts that I've drawn in detail not being able to be seen is a con.

7. If Japan's censorship laws were removed, would your drawing process change? If so, how would it change?

If censoring genitals became unnecessary, I would fill in the [details of the] genitals more carefully, because I think the depiction of genitals is something that's asked of erotic manga. 


\section{Observations}

In the responses to this interviews, three general areas caught my interest. The first is regarding how they learned censorship standards for their own work. The second is the emotional responses to having their work censored. The third is what the artists consider the pros to censorship to be. These three areas are rarely, if at all, discussed in erotic manga academic literature, so I find them to be quite insightful.

One of the earliest questions that led me to this research topic was "How do I censor an erotic comic?" That question has no definite answer, although it sounds simple. In my experience, different self-published comic events such as Comiket (short for Comic Market) and Comic City have different censorship standards, but there isn't a definitive guide anywhere. According to these responses, erotic manga magazines work in a similar fashion; each publisher has its own set of standards for its magazines and typically a seperate one for its books. These standards are maintained by the editing department, not the artists themselves. For example Aoi Miharu, who doesn't have experience self-publishing manga and has the editing department censor their work on their behalf, finds some positives in censorship. On the other hand Poccora, who used to do professional manga and now focuses only on self-published manga, sees censorship as more of a nuisance, in part because they have to censor their work themselves. Overall, erotic manga artists seem to learn from referencing other erotic manga works, from their superiors, and from being advised by the publishers they work for. If I were to pursue this question further, it would be interesting to ask erotic manga artists who were active in the 1990s or the current editing departments of the publishers the interviewee artists work for. Although, 
with such ambiguity surrounding Article 175 and its definition of “obscene," it's difficult to say if there is a definite answer to be found.

The artists' responses to the question of emotional response to the censorship of their erotic manga seemed to all fall within the Kübler-Ross model, colloquially known as the five stages of grief: denial, anger, bargaining, depression, and acceptance. Of course, these stages do not happen in this order, and some may not happen at all; everyone has an individual process of grief. This is reflected in the responses of all of the interviewees in one way or another. Depression is shown in Afostarsan’s response of “It makes me very sad (とても悲しくなりま す).” and Yamada Konayuki’s “It’s very unfortunate... (とても残念です).” Anger is shown in Poccora’s quote “It feels stupid... (無駄な).” Aoi Miharu represents both acceptance and more notably bargaining with their suggestion "If I could, I think it'd be good to leave only one thing uncensored per work (もしできるなら、作品の中で一つだけ無修正があったらいいなあっとは 思いますが)” in response to question five. Though MEME50's response to question four is less of an emotion than a theory, they reveal their emotional perspective in their response to question five, “The fact that it's done so that minors won't see it? Even though erotic manga is made specifically for adults." There is a sentimental nuance of this "even though" lost in English translation. MEME50 uses noni, which is one of several particles that can be translated as "but" or "even though" in Japanese. What separates noni from other particles of this type such as kedo or demo is that noni has a feeling of dissatisfaction or an unpleasant surprise, while the other two do not have this emotional connotation. Though MEME50's responses have an air of professional neutrality and emotional distancing from the topic, this small grammatical point betrays that MEME50 is dismayed at the hypocrisy of censoring adult content made for 
consenting adult consumers. No artist in these interviews has the same emotional reaction to the censorship of their erotic manga as that of another; erotic manga or not, every artist has their own emotions regarding their works. The one commonality found is that the emotions that do spring up in these responses is that they can all be interpreted as indicative of a feeling of grief, mourning the loss of their own creation.

For the question regarding the pros of censorship, the answers were pretty split between "there are no pros" and "there are some pros," but the somewhat unexpected positive responses to censorship are what further complicate the entire concept of erotic manga censorship. The Japanese language betrays this complexity as well; although I have been using the word "censorship" in this paper, the actual Japanese word is shüsei, which can mean "amending," "retouching," "modification," etc. In translation, the Japanese word for erotic manga censorship, shüsei has a less negative connotation than ken'etsu, the word that actually means censorship in Japanese. Examining the responses that defend erotic manga censorship from Afostarsan and Aoi Miharu, they both mention that censorship helps self-restrain both the artists and the readers from going too wild. This corresponds with The Society to Protect the Freedom of Expression in Manga member Satonaka Machiko’s suggestion that artists be free to censor themselves without interference of agencies. Although, Afostarsan and Aoi Miharu also mention their lack of choice; Aoi Miharu says "If I could, I think it'd be good to leave only one thing uncensored per work," and in response to the question about whether their process would change if the censorship laws were removed, Afostarsan says "I would draw after using my own judgement to decide what should be hidden and what should be revealed." This indicates that even though these artists may self-censor, there is still an omnipresent force that prevents them from having complete control 
over their own works. The answers that are against censorship from Poccora and Yamada Konayuki represent another side of the angle that unwittingly shows a positive point of censorship. They are both against it, especially Poccora, and this attitude is mentioned by Kimi Rito:

Within the manga genre, artists' drawings are inevitably "censored" in erotic manga, but beyond a reluctantly inseparable relationship, the relationship between erotic manga and censorship is like that of siblings. Their personalities are complete opposites, but precisely because there is a process of censoring genitals, artists and editors have cunningly used the process and devised ways to make lascivious work in spite of the erasure. Indeed, the use of censorship has become a manga expression in and of itself. As the creator is subjected to regulation, he fights back with a burning passion of rebellion with just as much fervor. The expressions of "cross-sections" and "tentacles" were birthed from the aforementioned spirit of rebellion, but to the authors and readers, they are never as much of a nuisance as genital censorship. Nevertheless, after learning the history and reasons for censorship, and censorship methods' individual characteristics and quirks, though it's a detestable thing, there are some aspects that come to light that are hard to hate.

While censorship, being a loaded word in itself, has many cons, the adversity it provides has led to new and interesting creative solutions. After examining the history of erotic manga censorship, the styles in which one can censor their work, and the statements from the interviewees, this passage rings a bit of truth; although erotic manga censorship is a nuisance overall, every sunlight-obscuring black cloud has a silver lining. 
As of the time of writing, erotic manga censorship is still in effect, but notable things are happening in Japanese society that may lead to changes in the future. In early 2019, three major convenience stores, Seven-Eleven, Lawson, and FamilyMart, agreed to stop selling adult-oriented magazines "for the sake of women, children, and foreign tourists visiting for the Rugby World Cup and the Olympics.” Although some people, such as Kinzo, in his news article "How Far until it Becomes an Erotic Book? Defining the Vague Boundary Line through Convenience Stores' Suspension of 'Adult Magazine' Sales," theorize that rather than removing the magazines for the sake of women, children, and tourists, the convenience stores agreed to remove them because they have been selling poorly in recent years, and the Olympics provide an excuse as to not bring up the discussion of freedom of expression. These convenience store chains have gone through with the removal, and as of November 2019 they currently do not carry adult magazines. Even more recently, on November 16th, Japanese politician and president of the political party Protection of the Freedom of Expression Association (Hyoggen no Jiyu wo Mamoru Kai) Yamada Tarō brought up revising Article 175 in a public forum. He discussed negotiating with police and other relevant parties to make uncensored two-dimensional drawings and the genitals of consenting individuals legal. According to this proposal, actual child pornography would continue to be illegal, nonconsenting individuals would continue to have their content censored, and the viewing of adult content by minors would still be banned (Okotatsu). With societal forces rocking the boat of the vague, looming law that is the Obscenity Act, this research paper may not be applicable in a decade from now, or it could become increasingly relevant. Either way, the censorship of erotic manga will remain an important piece of history for not only erotic manga, but for manga and the freedom of expression in art at large. 


\section{Acknowledgements}

I would like to thank multiple people for supporting me throughout this project, as without them this project would not be possible. First I would like to thank Dr. Jon Holt for his advice and recommendations regarding this project and throughout my upper-level academic career in its entirety. I am also grateful to Kimi Rito for sharing his expertise with me personally and clearing up some questions that I had. In this vein, I would like to extend thanks to Aoi Miharu, MEME50, Poccora, and Yamada Konayuki for giving their time and thoughts for the interview, and a big thanks to Afostarsan for not only participating in the interview but also providing some of their comics about censorship and allowing me to translate and letter them for use in this paper. Lastly, I would like to thank Hirai Yūichi for his help in Japanese proofreading and his emotional support. 


\title{
Appendix
}

\section{Full Japanese Interview Responses}

\begin{abstract}
Ahostarsan
1. 自分で本を読んでおぼえた事と、先輩漫画家や編集者に教えてもらった事と両方あ ります。
\end{abstract}

2. モザイク・黒ベタ・かわいいキャラクターの顔イラストそのもので隠す。

3.ほとんど先に全部描きます。

4. とても悲しくなります。「この修正に意義はあるのかな?」と思います。

5.「なんでもかんでも OK」という無謀な気持ちをセーブする、歯止めになる役割があ ると思います。

6. 隠さなくてもよい、隠すべきでないものまでどんどん浸食されていきそうで怖いで す。

7. 自分自身の判断で「隠したほうが良いもの」「出したほうが良いもの」を決めて描 きます。修正だけでなく、内容やセリフなど漫画全体を見て自重する部分を決定しま す。 


\section{Aoi Miharu}

1. 私は同人誌の経験がないので、仕事のほとんどが出版社で修正をやってくれていま すが、二回ほど修正をした経験があり、そのときは出版社からの指示があり、修正し ておりました。

2. 自分で修正をする場合は出版社の指示で性器を真っ白に塗っていました。

3. 時間がないとき以外は全部描いております。

4.これといって特別な感情はありませんが、無修正版を公開できる場があるといい なあっとは思います。ただ、修正がまったく無いものが出回りすぎると、モラル等と は関係なく、修正が入ることによって醸し出されるインモラルな雾囲気が損なわれる 気もします。

過度な修正にはあまり良いイメージはありません。

5. 修正が入ることによる背徳感。すべてをあけっぴろげに丸見えにすることが当たり 前になると、ある種原始人のそれを見る感覚に近く、エロさが損なわれる気がしま す。

もしできるなら、作品の中で一つだけ無修正があったらいいなあっとは思いますが。

6. 作者としても、読者からしても、せっかく綺麗に描いた絵が見えない 
7. 作品によりますが、なくなったことによって見せられる部分等をより鮮明にクロー ズアップした描き方をするかもしれません。一般誌に関しても場合によって同じこと が言えるかと思います。

\section{Meme50}

1. 同人誌は、先に活動されていた作家さんの漫画を参考にしました。

商業誌の修正は編集部が行います。

2. 海苔型黒ベタを使用します。

3. 修正で隠れる部分も全部描きます。

4. 日本国内では性器を修正しなければ漫画を発表できませんが、日本の読者様にも無 修正お見せしたいという気持ちはあります。

5. 未成年の目に入らないようにできるところ?

エロ漫画は大人の為の読み物なのに。

6. 場合によっては演出の妨げになるところ

7. 私は変わらないと思います。 


\section{Poccora}

1. 持っていた同人誌の模倣と、コミックマーケットの公式アナウンスから学びまし た。

2. 海苔黒ベタのみです。頒布するプラットフォームに合わせます。

3. 全部を描きます。なぜなら、海苔黒ベタは描き込みが見えるため。

4. 無駄な作業だと感じます。クリエイターにもユーザーにも求められていないと感じ るからです。

5. 無いです。

6. 表現したかった部分が、やむを得ず消えてしまうこと場合があります。また、工数 がかかります。

7. 修正を考慮した描き方をしているわけではないので、あまり変わらないと思いま す。 


\section{Yamada Konayuki}

1. もともとエロ漫画が好きで、雑誌や単行本を買っていたので、どの程度修正すれば 良いかはいつのまにか知っていました。また、同人誌を作っているのですが、修正が 足りない時は同人誌印刷所の方が注意してくれるので、その都度知識をアップデート しています。

2. 同人誌では

*イラスト部分には海苔型黒ベタ

*言葉には○

商業雑誌では

*その雑誌準拠の処理を編集部が行います

3. 修正で消されてしまう部分も描いています。

4. せっかく頑張って描いたものを見せられないのは、とても残念です。

5. 私は局部修正の必要性がわからないので、良いポイントは思いつきません

6. 漫画家目線としては、細部まで描いたものを見せられないことが悪いポイントだと 思います

7. 局部修正の必要がなくなるのであれば、さらに局部を丁寧に書き込みます。エロ漫 画に求められているのは、局部の描写だと思っているので。 


\section{Bibliography}

Berndt, Jacqueline. "Manga Studies \#1: Introduction by Jaqueline Berndt.” Comics Forum, 11 May 2014, https://comicsforum.org/2014/05/11/manga-studies-1-introduction-byjaqueline-berndt/. Accessed 10 May 2019.

Brienza, Casey. “Sociological Perspectives on Japanese Manga in America.” Sociology Compass, vol. 8, no. 5, 2014, pp. 219-234.

Dobbins, Amanda. "Obscenity in Japan: Moral Guidance without Legal Guidance" ExpressO (2009) Available at: http://works.bepress.com/amanda_dobbins/1/.

Ero-Manga-Studies.com. http://ero.manga-studies.com/. Accessed 10 May 2019.

Joyce, Colin. "Comics can be pornographic, rules Japanese judge.”

The Telegraph. Tokyo. 14 Jan 2004. https:/www.telegraph.co.uk/news/worldnews/ asia/japan/1451646/Comics-can-be-pornographic-rules-Japanese-judge.html. Accessed 13 Nov 2019.

Kimi, Rito. “Comic X-Eros 50 Issue Retrospect.” Comic X-Eros, Feb. 2017.

Kimi, Rito. Eromanga Hyōgen-shi (The History of Ero-Manga Expression). Ōhta Publishing, 2017.

Kimi, Rito. Hentai Manga! A Brief History of Pornographic Comics in Japan. Taiyō Publishing, 2016.

Kinsella, Sharon. Adult Manga: Culture and Power in Contemporary Japan. Routledge, 2000.

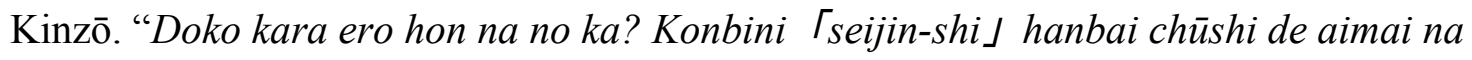
kyōkai-sen ni kirikomu" (How Far until it Becomes an Erotic Book? Defining the 
Vague Boundary Line through Convenience Stores' Suspension of 'Adult Magazine' sales). SPA!, 17 Mar. 2019. https://nikkan-spa.jp/1558971. Accessed 10 May 2019.

Nagaoka, Yoshiyuki. Manga wa Naze Kisei Sareru no ka - 「Yūgai」 o Meguru Hanseiki no $K \bar{o} b \bar{o}$ (Why is Manga Regulated? Half a Century of "Harm”). Heibonsha, 2010.

Nagayama, Kaoru. Zōho Eromanga • Sutadīzu: 「Kairaku Sōchi」 Toshite no Manga Nyuumon (Eromanga Studies: The Introduction to Manga as a "Pleasure Device"). Chikuma Shobou, 2014.

Natsui, Takato. "Cybercrimes in Japan: Recent Cases, Legislations, Problems and Perspectives." NetSafe II: Society, Safety \& the Internet. 2003.

Nihon Manga Gakkai (Japan Society for Studies in Cartoons and Comics). https://www.jsscc.net/. Accessed 10 May 2019.

Noppe, Nele. "Dōjinshi Research as a Site of Opportunity for Manga Studies." Comics Worlds and the World of Comics: Towards Scholarship on a Global Scale, vol 1, 2010, pp. $115-131$.

Okotatsu, Doragon (okotatsudoragon). “Keihō 175 jō no adaruto sakuhin no shūsei ni tsuite. Shakai hōeki kara kojin hōeki ni kaete iku koto de, hi jitsuzai 2 jigen ya honnin dōi no seiki no mushusei hyōgen ga ihō to naranai yō keisatsu ya kankei kakusho to negoshiēshonchū to no koto. Riaru miseinen, honnin hidōi, seishōnen no shichō wa hikitsudzuki ihō no hōkō." 16 November 2019, 11:00 a.m. Tweet.

“Penal Code". Japanese Law Translation, http://www.japaneselawtranslation.go.jp $\underline{\text { law/detail/ } \mathrm{id}=1960 \& v m=04 \& \mathrm{re}=02}$. Accessed 19 May 2019.

Rubin, Jay. Injurious to Public Morals: Writers and the Meiji State. University of Washington 
Press, 1984.

Schodt, Frederik L. Dreamland Japan: Writings on Modern Manga. Stone Bridge Press, 1996.

Schodt, Frederik L. Manga! Manga!: The World of Japanese Comics. Kodansha International, 2013

Shirata, Hideaki. Sei Hyōgen Kisei no Bunka-shi (The Cultural History of the Regulation of Sexual Expression). Akishobo, 2017.

SPA! Press. "Ero hon wa konbini hanbai teishi de horobiru no ka? 「Saraba, erogurabiaten」 ni kakeru omoi" (Are erotic books going extinct because of the suspension of sales in convenience stores? I wager that if that is the case, there will be erotic and gravure exhibitions). SPA! 27 Feb. 2019. https://nikkan-spa.jp/1552213. Accessed 10 May 2019.

Sudou, Jun. "Heya ni Haitta Masukomi" (The Mass Media That Entered His Room). 「Miyazaki Tsutomu Jiken Enzai-setsu」 wo Kenshō Suru (Examining the Theory of Miyazaki Tsutomu's Innocence), http://std2g.web.fc2.com/masscomm/masscomm.html. Accessed 10 May 2019.

Takasu, Motoji. “Konbini de 「hanbai chūshi 」... 「ero hon」 wa shimei wo oete shimatta no ka" ('Cancellation of Sales' in Convenience Stores'... Have 'Erotic Books' Completed Their Mission?) Zakzak, 24 Jan. 2019. https://www.zakzak. co.jp/ent/news/190124/ent19012410010-n1.html. Accessed 10 May 2019.

Thompson, Jason. Manga: The Complete Guide. Del Rey, 2007.

Treat, John. "Yoshimoto Banana Writes Home: Shōjo Culture and the Nostalgic Subject." Journal of Japanese Studies, Vol. 19, No. 2, 1993, pp. 353-378. 